\title{
PEMBENTUKKAN DAN PENDALAMAN PROSES BERPIKIR MENDESIGN, KETERKAITAN PROSES AJAR DAN PEMAHAMAN TAHAPAN PEMIKIRAN PROSES MENDESIGN DARI SISI PENDIDIKAN HINGGA LINGKUP PROFESI
}

\author{
Paulus S Whanarahardja, Dipl. Des. M.T. \\ Program Studi Desain Interior - Universitas Pelita Harapan \\ paulus.whanaradja@uph.edu
}

\begin{abstract}
Abstrak - Makalah menjelaskan kompleksitas materi ajar bagi peserta didik Program Studi Desain Interior yang memerlukan media tersendiri selain dari RPS (Rencana Pengajaran Semester). Kompleksitas tata laksana pendidikan desain terciptakan oleh ketentuan, peraturan dan sejumlah materi ajar yang meliputi teori, teknis, desain itu sendiri dan attitude. Mata kuliah studio desain dengan sistem integratif didukung oleh berbagai mata kuliah pendukung yang memusatkan perhatiannya pada tema yang diangkat oleh studio. Oleh karena itu, hasilnya bersifat komprehensif dan tepat sasaran. Metode deskriptif digunakan dalam bentuk tabel yang menggambarkan keterkaitan situasi pelaksanaan dan wawasan kompleksitas materi ajar. Tujuan utama yang ingin dicapai adalah membentuk "benang merah" yang dapat dicermati sebagai acuan penyusunan tahapan dan proses ajar mengajar. Laporan dan komentar dari pengguna peserta didik menjadi bahan evaluasi proses pengajaran dan pembekalan pada proses pendidikan yang lebih baik. Dengan demikian, koreksi didapatkan untuk mempersiapkan Kurikulum dan RPS yang semakin "compatible" dengan kebutuhan dunia keprofesian Desain Interior.
\end{abstract}

Kata kunci : desain interior, sistem integratif, deskriptif, materi ajar

\section{PENDAHULUAN}

Sering terdengar opini dari dunia profesi yang menganggap bahwa beberapa hal pada proses desain yang digunakan di dunia akademik tidak semuanya diperlukan di dunia keprofesian. Perbedaan pengetahuan dan tata laksana operasional desain antara dunia pendidikan dan praktek, terkait dengan keadaan dan berbagai macam faktor di dalamnya, menjadikan pengertian desain pada kedua kubu tersebut berbeda. Hal ini akan dibahas dan dirangkum dalam bentuk bagan alir untuk menjelaskan secara detil yang terdapat pada tata laksana, pengertian dan desain melalui dunia akademik. Terkandung di dalamnya adalah gambaran dan arahan tata laksana dan tahapan berpikir, pola penjajakan dan pengumpulan data/informasi.

\section{METODE PENELITIAN}

Metode yang digunakan berupa wawancara tidak berstruktur Zhang, Y. , \& Wildemuth, B. M. (2009) pada mahasiswa bimbingan yang bekerja praktek di perusahaan=perusahaan interior selama lima tahun terakahir. 


\section{HASIL PENELITIAN}

Hasil wawancara dan studi literature dirangkum dalam bagan alir dan tabel. Diharapkan penjelasan bagan alir dapat memberikan gambaran jelas bahwa proses mendesain di dunia akademik merupakan bagian daripada perkenalan sekaligus pembentukan pemahaman serta pembekalan tentang tahapan mendesain yang seharusnya terjadi. Pada bagan alir yang terdiri dari dari tiga kolom menjabarkan tata laksana studio desain termasuk pertimbangan penulisan dan proses yang digunakan pada dunia profesi. Bagan alir tersebut juga menjelaskan bahwa yang membedakan desain pada proses sebenarnya adalah kemampuan dan pengalaman desainer dalam pengolahan data dan informasi yang efisien dan efektif. Faktor lainnya adalah, bahwa desainer yang bersangkutan memusatkan perhatiannya pada suatu bidang keahlian.

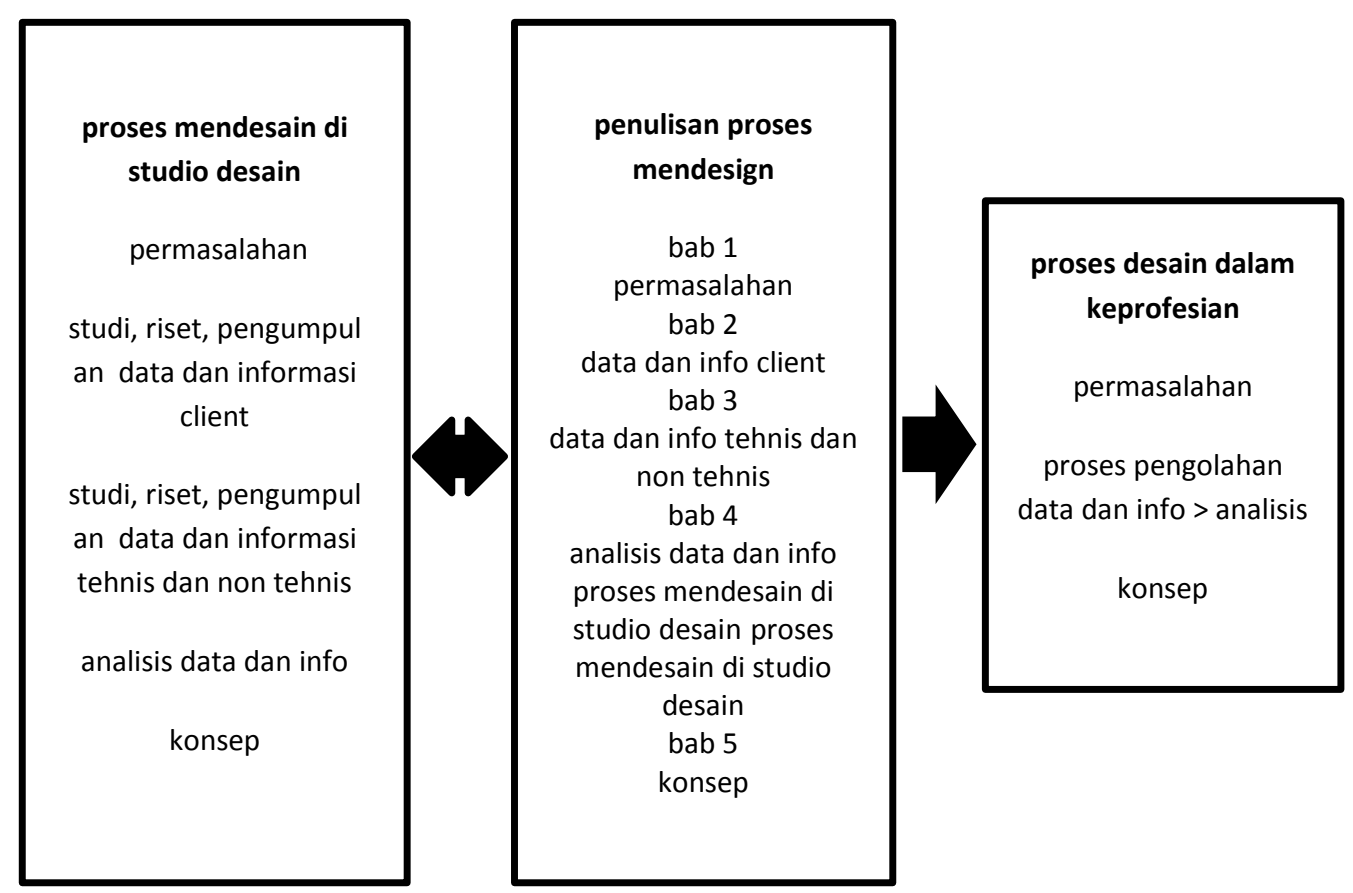

Gambar 1. Tahapan Ajar Mengajar Mendesign terhadap Dunia Profesi Hasil studi dan research penulis 2010 - 2016

Bagan alir di atas terdiri dari tiga kolom yang menjelaskan proses mendesain pada tiap tahap peraihan pendidikan desain. Kolom pertama dan kedua menjelaskan tentang 
pengelolaan desain di dunia praktek. Kolom ketiga menjelaskan proses desain tiap tahap secara mudah dan bersamaan pada satu tabel yang bersebelahan. Pada gambar tata laksana studio dapat dicermati bahwasanya alur pertama adalah tahap pencarian data dan informasi yang dilaksanakan oleh peserta didik. Data disertai dengan studi teknis seperti jalur, cakupan dan lingkup aktivitas terkait ergonomi, psikologi, kesehatan, elektrikal dan MEP (Mekanikal, Engineering dan Plumbing).

Di sini diperkenalkan permasalahan yang dialami oleh pengguna serupa dengan permasalahan keseharian yang dirasakan oleh para peserta didik. Kemudian, diperkenalkan hal-hal terkait teknis (material, warna dan konstruksi), ergonomi (standar keamanan, kenyamanan dan kesehatan), gambar (dimensi, proporsi, skala), dan presentasi (gambar kerja, penulisan, poster dan materi presentasi yang lain). Kegiatan dasar pada proses awal mendesain ini merupakan sikap dasar yang ditanamkan dan diterapkan pada peserta didik yang akan terus diberlakukan pada mata kuliah studio berikutnya.

\section{Desain dalam manajemen desain}

Hesket (2005:3) mengatakan "design is to design a design to produce a design" yang dalam uraiannya memberikan pengertian tentang design yaitu design as a field (desain merupakan kegiatan beberapa bidang yang berkaitan dengan desain itu sendiri, kreatif industri, multimedia dan modeling). Design as an action or process (desain berkaitan dengan tahapan aksi/aktivitas menuju tujuan/hasil). Design as a concept or proposal (pembentukan konsep melalui studi lokasi, pengguna dan faktor pendukung lainnya yang telah melalui tahap analisis). Design as an outcome (hasil dari proses desain merupakan juga suatu desain yang hasilnya sesuai rencana, Design is an attitude not a profession (desainer interior dalam berproses menjadi pendengar, mendata, mengakomodasikan dan menerjemahkan sepenuhnya kebutuhan pengguna. Pengertian dan urutan kronologi dari Hesket sebenarnya dijalankan di kebanyakan institusi pendidikan desain di Indonesia. Pada gambar terlampir dijelaskan skema jenjang dan konten pendidikan desain yang diberikan di Program Studi Desain Interior Universitas Pelita Harapan.

Gambar Alur dan Tata Laksana pada gambar terlampir menjelaskan posisi design dalam manajemen design itu sendiri dan yang lebih menjelaskan adalah bagaimana proses dan jenjang menjadi desainer dimulai dari tahap pendidikan dan peran desainer pada masyarakat pengguna (pemilik, konsultan, kontraktor, vendor, supplier, tehnisi, cleaning service) 


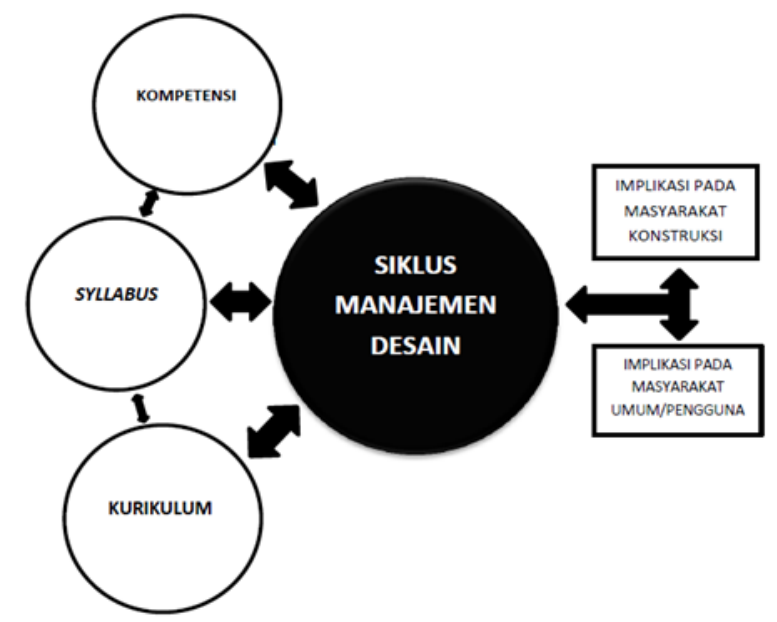

Gambar 2. Alur dan Jenjang Design pada tahap pendidikann dan tahap keprofesian Sumber ; hasil studi dan riset penulis 2012 - 2017

Penjelasan Bagan Alir

\section{Bubble Kompetensi}

berada pada ranah pendidikan, berisi daftar kompetensi program studi yang disusun melalui penelitian dan studi banding terhadap program studi yang sama pada beberapa perguruan tinggi di New Zealand, Amerika, Kaiserslautern (Jerman). Sampel diambil ketika rekan-rekan dosen studi di negaranegara tersebut. Penilitian dan studi banding juga dilakukan pada beberapa asosiasi profesi yaitu HDII, IAI dan UIA. Kompetensi ditentukan dengan kesesuaian, kesamaan dan keselarasan visi misi universitas. Tiap butir kompetensi mengacu pada proses pembentukan calon desainer yang layak, terutama pada program studi Desain Interior.

Bubble Syllabus masih dalam ranah pendidikan, memuat butir-butir kompetensi sebagai landasan untuk memperkuat satuan mata kuliah yang secara keseluruhan tampil dalam RPS (Rencana Pembelajaran Semester)

Bubble Kurikulum menampilkan materi-materi pengajaran yang terbagi dalam empat kriteria besar, secara keseluruhan mewakili tahapan operasional desain interior di dunia praktek. Pertama, teori tentang desain, pengetahuan manajemen, ergonomi, legal, ekonomi, psikologi, seni sosial dan budaya. Kedua, keteknikan material, konstruksi, mechanical engineering dan plumbing, sistem bangunan, listrik dan lain lain. Ketiga, desain menjelaskan metode dan pola mencari data, mengolah data hingga peletakan analisis sebelum menetapkan konsep yaitu dengan empat karakter desainer yang menerjemahkan 
kebutuhan, keinginan dan tujuan daripada pengguna. Heskett menyebut desainer interior "is an attitude not profession. An Interior Designer is someone who plans, researches, coordinates and manages such projects." Karakter menentukan keberhasilan proses desain yang baik.

\section{Bubble Siklus Manajemen Desain}

menunjukkan siklus manajemen desain yang serupa dengan manajemen konstruksi. Siklus ini dijalankan tepat waktu, tepat guna dan tepat biaya. Selanjutnya, dilakukan studi kelayakan untuk melengkapi pembahasan permasalahan dan tujuan perancangan.

Tahap Studi Kelayakan

Tahap Perencanaan, menyatakan implementasi solusi permasalahan disertai aspek-aspek penting yang tercakup dalam proses desain.

Tahap

Procurement/Persiapan, menerjemahkan hasil perancangan untuk perhitungan dana proyek, ketersediaan dana, waktu (penjadwalan), material dan sumber daya manusia - hingga akhir proyek (serah terima), pengendalian mutu.

Tahap Konstruksi/Pelaksanaan, meliputi tahap pembangunan, pengawasan dan pengendalian mutu.

Tahap Operasional, merupakan tahap penggunaan yang dilakukan oleh operator lain.
Tahap Perawatan, berada di bawah pengawasan operator.

Konten pada Bubble ini termuat lebih terperinci di Bubble Kurikulum pada bagian penjelasan materi pengajaran dan tata laksana pengajaran di masing-masing studio sesuai tingkat kesulitannya. Studio Retail hingga Studio Partisipatori juga berproses dengan siklus mendesain yang sama. Perbedaannya adalah bobot dari keempat kriteria materi pengajaran pada teori, teknik, desain dan karakter yang semakin rumit.

Bubble Implikasi pada Masyarakat Konstruksi menunjukkan siklus pada Bubble Kompetensi hingga Bubble Implikasi pada Masyarakat Konstruksi yang menjelaskan tahapan pendidikan seseorang menjadi Desainer Interior. Tahapan tersebut memberikan pembekalan dan wawasan dan lingkup pada desain. Bubble Implikasi pada Masyarakat Konstruksi ini para interior desainer pemula dihadapkan dan dilibatkan langsung dengan para pelaku konstruksi, supplier dan vendor. Di kolom ini juga secara rinci dijelaskan unsurunsur dan komponen-komponen yang tercakup dalam kegiatan masyarakat konstruksi secara teori dan pengajaran yang tergambar pada Bubble Kurikulum dan Bubble Siklus Manajemen Desain.

Bubble Implikasi pada Masyarakat Pengguna berhubungan dengan salah satu pembahasan Hesket yang menyatakan, "design is an 
attitude not a profession". Profesi sebagai desainer bukan sekedar memberikan dan menghabiskan tenaga sekaligus pikiran pada penyelesaian suatu proyek. Proyek harus dijadikan bagian dari cara dan pola penyelesaian dengan segenap pikiran, 'hati' dan passion yang keluar dari kemampuan desainer.

Keenam Bubble alur besar pemetaan lingkup dan peran desain ini bertujuan untuk memudahkan peserta didik dan rekan dosen dalam menyusun strategi menghadapi pengertian, pembelajaran dan tata laksana desain. Proses ini merupakan siklus pembentuk kesadaran intuitif dalam mendesain dan keterkaitannya.

IV. SIMPULAN
Tata laksana kurikulum

Pada tabel dibawah (Tabel 1) ini dapat terbaca proses dan tahapan pembekalan peserta didik dari tahap awal hingga akhir. Tenggat waktu studi dan konten ajar mengajar meningkat seiring bertambahnya semester yang telah ditempuh. Tabel ini juga berisi konten-konten pelajaran yang berlandaskan RPS (Rencana Pembelajaran Semester) dan Kompetensi. Sebelum para peserta didik mengakhiri masa studi, mereka diharapkan lulus dengan pencapain profil kelulusan program studi Desain Interior. 


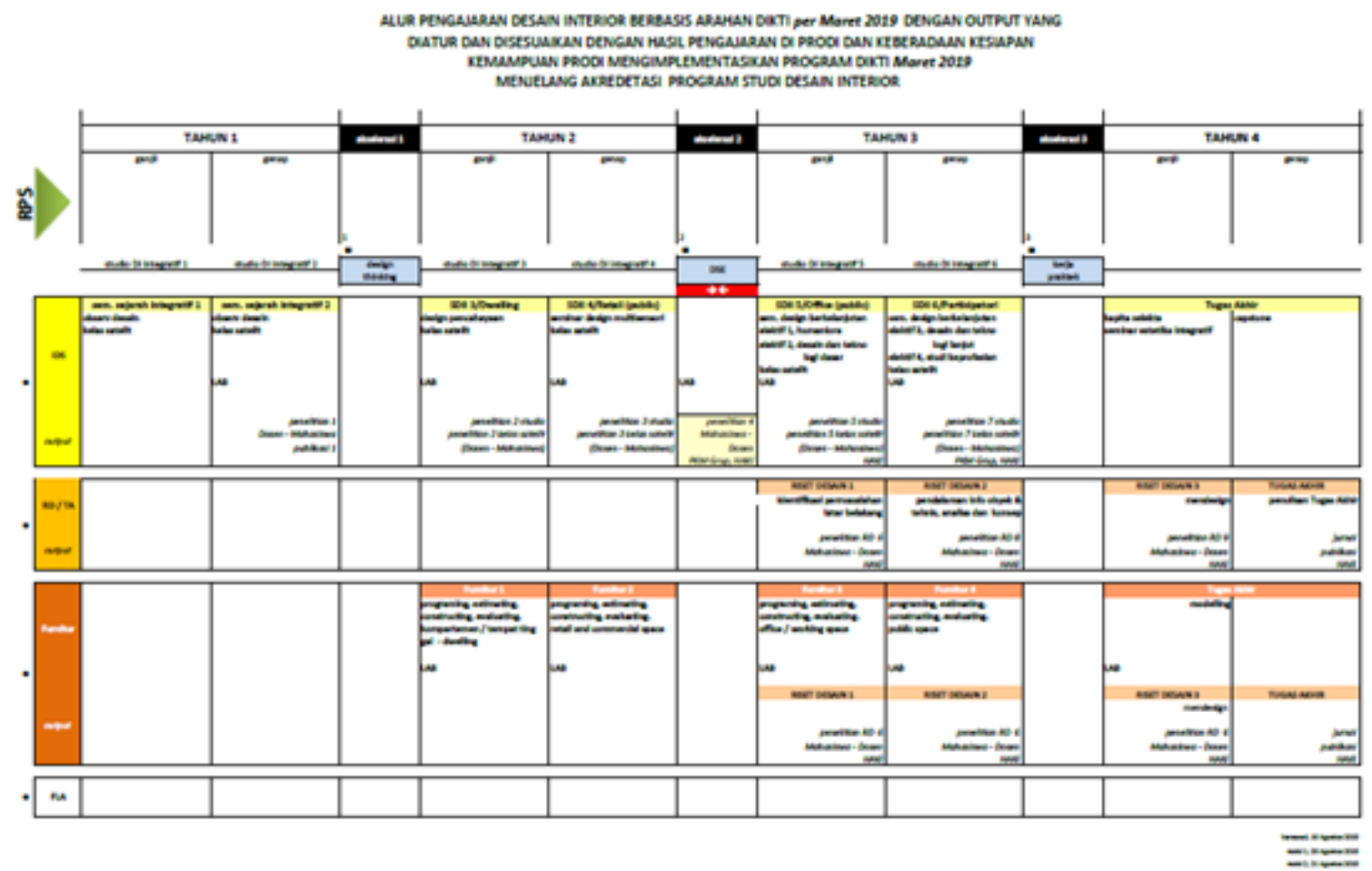

Tabel 1. Tata Laksana perkuliahan Program Studi Desain Interior

Universitas Pelita Harapan

Sumber : hasil rangkuman dan studi Program Studi 2019

DAFTAR PUSTAKA

Hesket, John. 2005. Design: A Very Short

introduction

Zhang, Y. , \& Wildemuth, B. M. (2009).

Unstructured interviews. In B. Wildemuth

(Ed.), Applications of Social Research

Methods to Questions in Information and

Library Science (pp.222-231). Westport, CT:

Libraries Unlimited 